\title{
SUMMARY OF WORKSHOP RECOMMENDATIONS
}

A special workshop among participants was conducted to assess the status of the aquaculture industry in Southeast Asia, particularly in Malaysia, Philippines, Singapore, and Thailand. Although hatchery, nursery, and grow-out culture techniques had already been developed for most of the economically important species cultured in Southeast Asia, the outcome of the workshop showed that there are still major constraints to be able to increase production. Further studies have to be conducted to have greater control of factors that lead to better production. The participants prioritized the economically important species and the research area for each species for the Region.

The summary of workshop recommendations are as follows:

\section{FINFISHES}

\section{A. Marine and Brackishwater}

Priority Species

Research Areas

1. Sea Bass

1. Diseases in nursery and grow-out
a. ciliates
b. bacteria
c. virus
d. stress-induced

2. Feed development for nursery

3. Feed development for grow-out

2. Grouper

1. Development of hatchery techniques

2. Development of feed for nursery

3. Development of artificial diet for grow-out

4. Diseases in nursery and grow-out
a. bacteria
b. virus
c. stress-induced

5. Diseases in nursery
a. ciliates

3. Red Snapper

1. Development of reliable hatchery techniques

2. Feed development for nursery

3. Diseases in nursery and grow-out
a. ciliates
b. bacteria 
4. Golden Snapper

5. Mullet

6. Rabbitfish

7. Milkfish

\section{B. Freshwater}

Priority Species

1. Red Tilapia c. virus

d. stress-induced

4. Development of artificial feed for grow-out

1. Development of reliable hatchery techniques

2. Development of feed for nursery

3. Development of feed for grow-out

4. Diseases in nursery and grow-out
a. bacteria
b. virus
c. stress-induced
d. ciliates

1. Development of hatchery techniques

2. Development of feed for grow-out

3. Development of feed for nursery

4. Diseases in nursery and grow-out
a. bacteria
b. virus
c. ciliates
d. stress-induced

1. Development of feed for grow-out

2. Development of reliable hatchery techniques

3. Development of feed for nursery

4. Diseases in nursery
a. ciliates
b. bacteria

5. Diseases in grow-out
a. Stress-induced
b. Bacterial and ciliate

1. Refinement of broodstock management technique

2. Development of practical diets for hatchery, nursery and grow-out

3. Development of disease prevention and control methods for hatchery, nursery and grow-out

4. Economic assessment of hatchery systems 
2. Marble Goby

3. Clarias sp.

4. Other Tilapias

5. Carps (Grass Carp)
1. Refinement of hatchery techniques

2. Feed development for nursery

3. Feed development for grow-out

1. Refinement of hatchery techniques

2. Feed development for nursery and grow-out

3. Selective breeding

1. Selective breeding

2. Feed development for nursery

3. Refinement of hatchery techniques

4. Feed development for grow-out

1. Refinement of hatchery techniques

\section{CRUSTACEANS}

Priority Species

1. Penaeus monodon

\section{Research Areas}

1. Development of captive broodstock

2. Development of economically feasible diets for grow-out

3. Development of economically feasible broodstock and larval diets

4. Refinement of existing hatchery-nursery technology ${ }^{1}$

5. Development of techniques for disease prevention and control in hatchery

6. Water management for grow-out

2. P. merguiensis/P. indicus 1. Development of economically-feasible diets for grow-out

2. Water management

3. Development of techniques for disease prevention and control

4. Development of captive broodstock

5. Refinement of existing hatchery-nursery technology

6. Selective breeding

3. Macrobrachium rosenbergii
1. Selective breeding

2. Refinement of existing hatchery-nursery technology ${ }^{1}$

3. Water management

\footnotetext{
${ }^{1}$ Includes feeds, disease prevention and control, and water management.
} 
4. Development of techniques for disease prevention and control

5. Feed development for grow-out

6. Development of captive broodstock

4. Scylla serrata

1. Refinement of existing hatchery-nursery technology ${ }^{1}$

2. Development of captive broodstock

3. Feed development for grow-out

4. Development of techniques for disease prevention and control

5. Water management for grow-out

5. Metapenaeus ensis/

M. monoceros

1. Development of captive broodstock

2. Water management for grow-out

3. Refinement of existing hatchery-nursery technology ${ }^{1}$

4. Feed development for grow-out

5. Development of techniques for disease prevention and control

III. MOLLUSCS AND SEAWEEDS

A. Molluscs

Priority Species

Research Areas

1. Perna viridis

1. Product development and other uses

2. Depuration

3. Resource evaluation

4. Site identification

5. Spatfall forecast

6. Transplantation

7. Evaluation of culture technology

8. Refinement of grow-out techniques

2. Crassostrea sp.

1. Resource evaluation

2. Site identification

3. Depuration

4. Spatfall forecast

5. Evaluation of culture technology

Includes feeds, disease prevention and control, and water management 
3. Anadara sp.

6. Product development and other uses

7. Transplantation

8. Refinement of grow-out techniques

1. Depuration

2. Resource evaluation

3. Site identification

4. Spatfall forecast

5. Transplantation

6. Product development and other uses

7. Development of hatchery techniques

8. Refinement of grow-out techniques

9. Evaluation of culture technology

4. Placuna placenta

1. Spatfall forecast

2. Resource evaluation

3. Development of hatchery techniques

4. Transplantation

5. Site identification

6. Refinement of grow-out techniques

7. Product development and other uses

\section{B. Seaweeds}

Priority Species

Research Areas

1. Gracilaria

1. Refinement of culture techniques

2. Basic biology

3. Product utilization

4. Screening and characterization of natural products

2. Porphyra

1. Basic biology

2. Refinement of culture techniques

3. Product utilization

4. Screening and characterization of natural products

3. Eucheuma

1. Refinement of culture techniques

2. Basic biology

3. Product utilization

4. Genetics/selective breeding and establishment of seed banks 